anthropology \& materialism

\section{Anthropology \& Materialism}

A Journal of Social Research

$3 \mid 2016$

Utopia: The Elsewhere and The Otherwise

\title{
The New in the Guise of the Old, the Old in the Guise of the New
}

Anna Artaker and Meike Schmidt-Gleim

\section{(2) OpenEdition}

Journals

\section{Electronic version}

URL: http://journals.openedition.org/am/596

DOI: $10.4000 / a m .596$

ISSN: 2364-0480

\section{Publisher:}

CETCOPRA, CRASSH - Center for Research in the Arts Social Sciences and Humanities, Fakultät

Gestaltung - Universität der Künste Berlin

\section{Electronic reference}

Anna Artaker and Meike Schmidt-Gleim, «The New in the Guise of the Old, the Old in the Guise of the New », Anthropology \& Materialism [Online], 3 | 2016, Online since 19 November 2016, connection on 01 May 2019. URL : http://journals.openedition.org/am/596 ; DOI : 10.4000/am.596

This text was automatically generated on 1 May 2019.

Tous droits réservés 


\title{
The New in the Guise of the Old, the Old in the Guise of the New
}

\author{
Anna Artaker and Meike Schmidt-Gleim
}

\section{EDITOR'S NOTE}

All images come from Anna Artaker and Meike Schmidt-Gleim, Counterparts, 2013. Vienna, Academy of Fine Arts. Selection of four pairs of puzzles, each puzzle 560 pieces, 42 x 30 $\mathrm{cm}$. Photos Ulrich Dertschei. The original pictures are from: Marilyn Bridges (fig. 1.1., The Pyramid Arena initially known as the Great American Pyramid on the banks of the Mississippi River, Memphis/Tennessee, 1994); Elke Hindemith (fig. 1.2., Giza Plateau on the outskirts of Cairo/Egypt, 1988); Derek Flynn / Marlborough Express (fig. 2.1., Waihopai Spy Base near Blenheim, New Zealand has its satellite dish cover deflated by protesters overnight, April 30, 2008) ; Claude-Nicolas Ledoux (fig. 2.2., Project for La Maison des Gardes Agricoles in Maupertuis, France, 1784); www.ilouvreparis.com (fig. 3.1., Orangerie in Versailles); Commander Leroy Chiao from the International Space Station (fig. 3.2., Palm Jumeirah resort in Dubai/United Arab Emirates under construction, 2005); Norman Johnston, The Human Cage: A Brief History of Prison Architecture , New York 1973, p. 19 (fig. 4.1., Interior Panopticon Cellhouse, Stateville Correctional Center in Crest Hill, Illinois/USA); Wikimedia Commons, David290 (fig. 4.2., Empty Section of the New South China Mall in Dongguan, Province of Guangdong/China, February 13, 2010). 
Fig. 1.1.

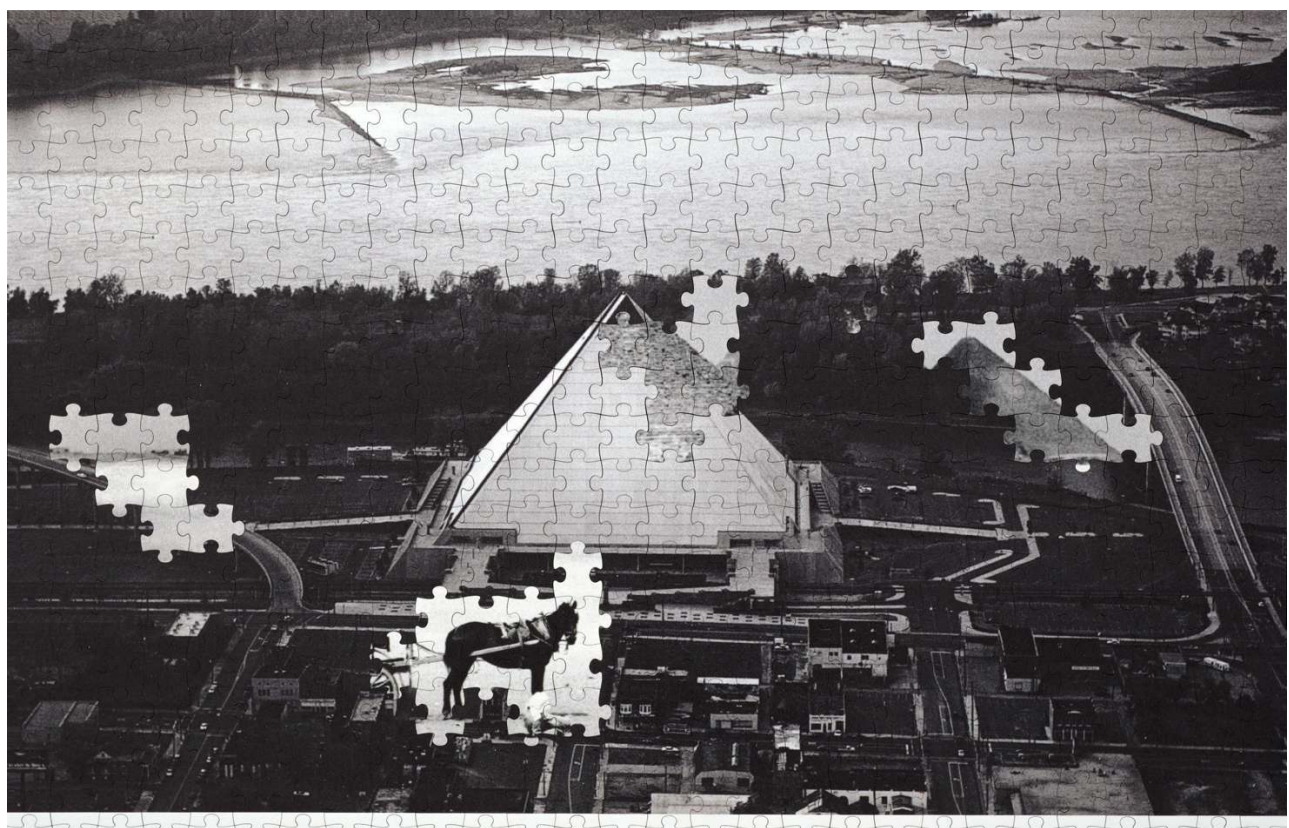

The Pyramid Arena initially-known as the Great American Pyramid-on the banks otthe Mississippi River, Memphiss Tennessee. Photo: Marydin Bridges 1994

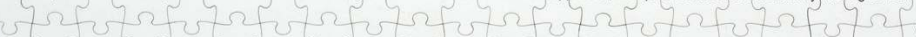

Fig. 1.2.

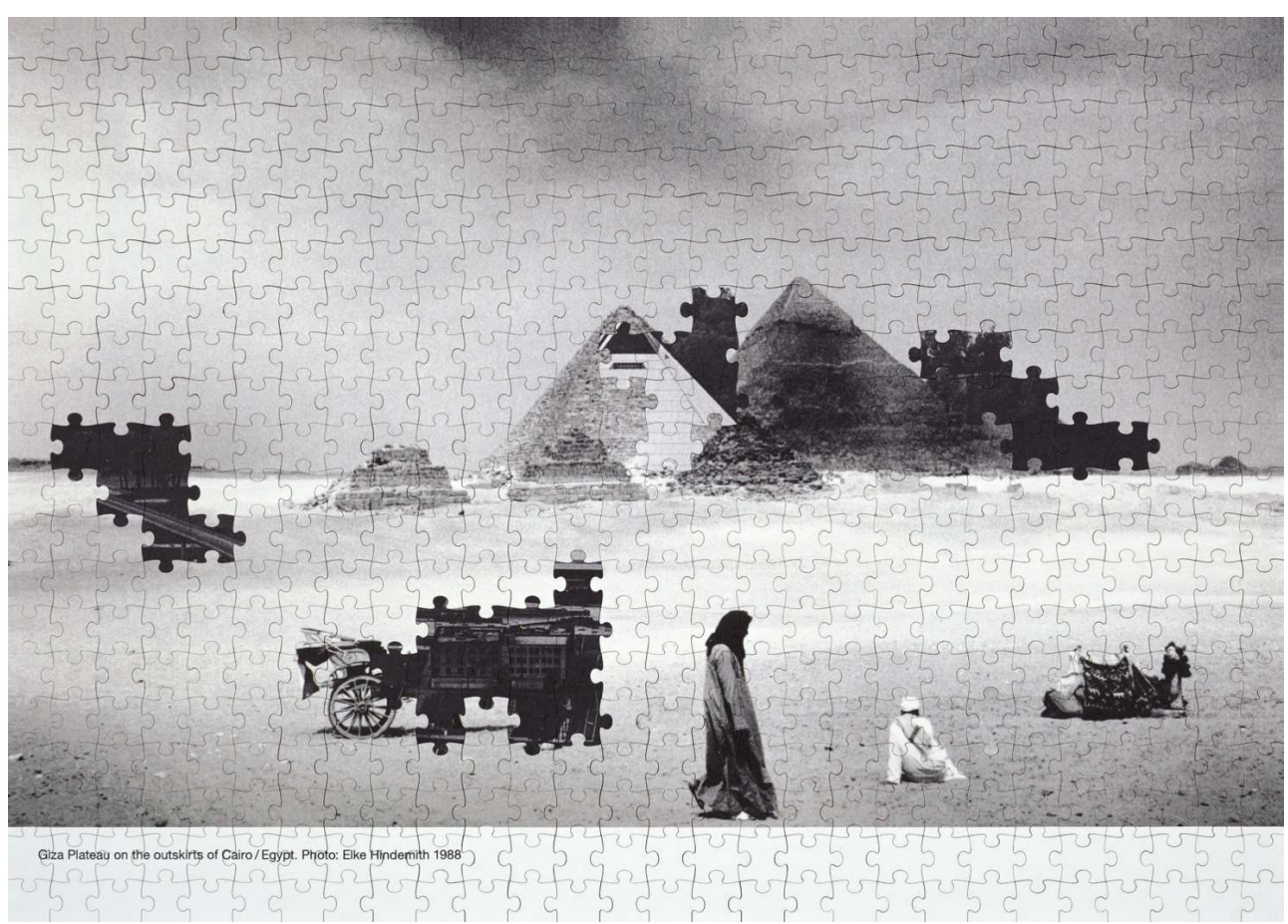


Fig. 2.1.

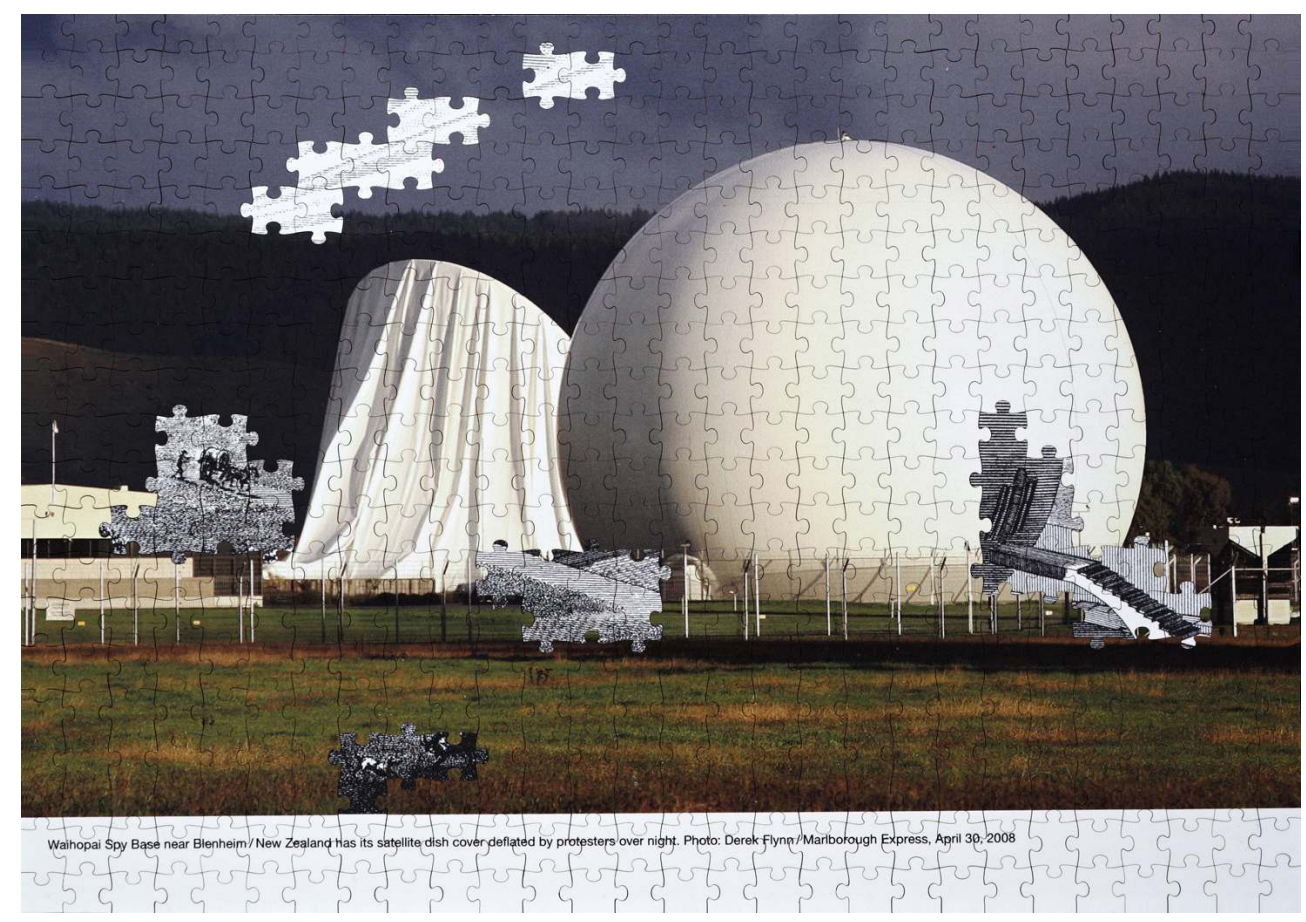

fig. 2.2.

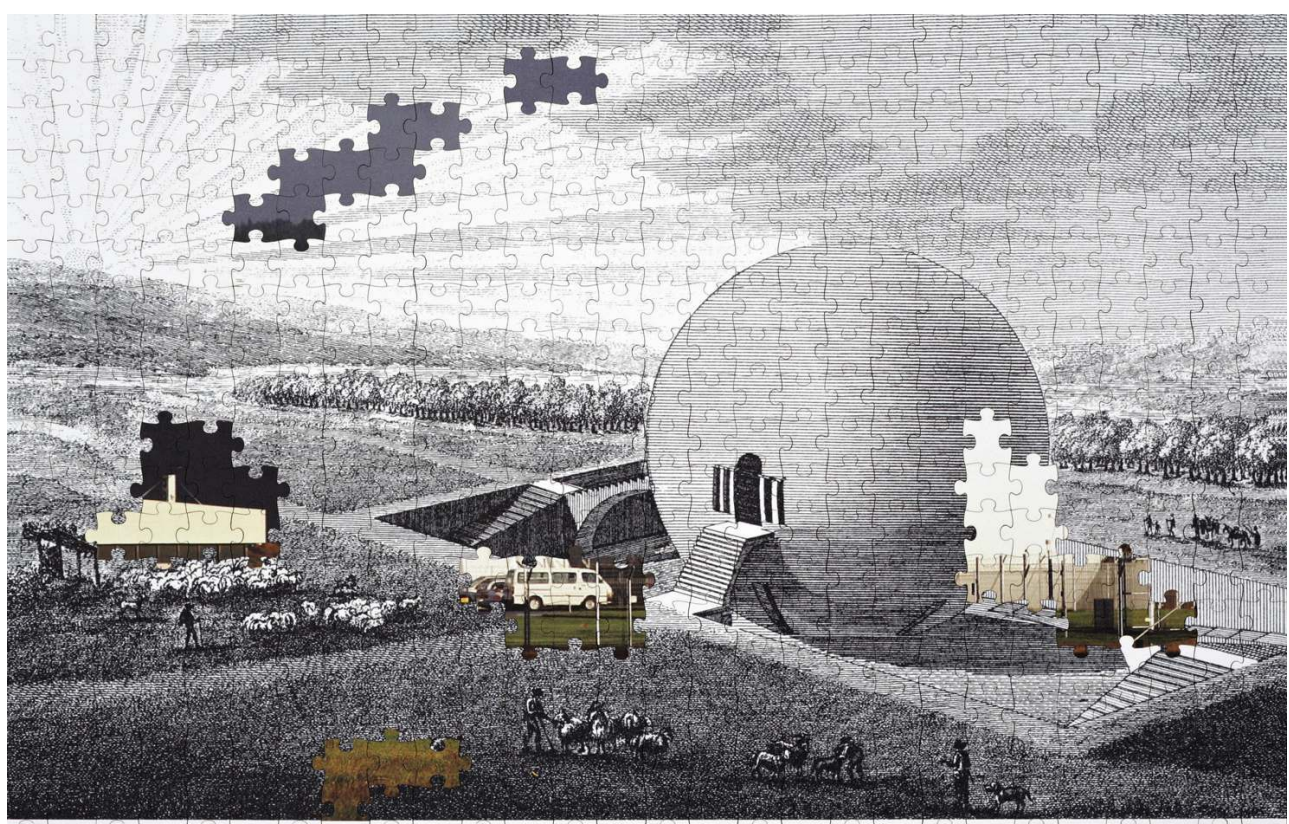

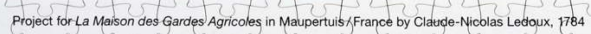


fig. 3.1.

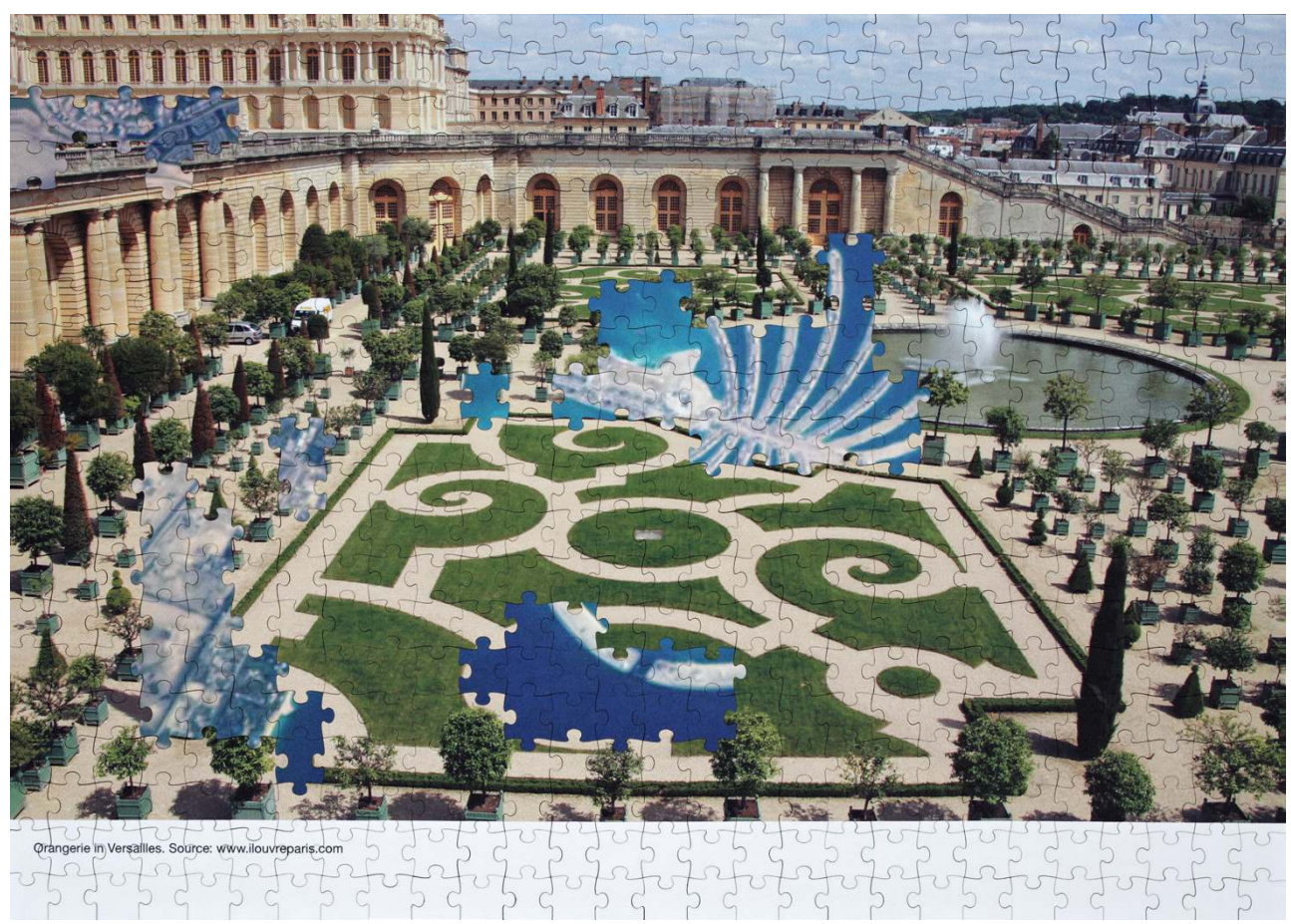

fig. 3.2 .

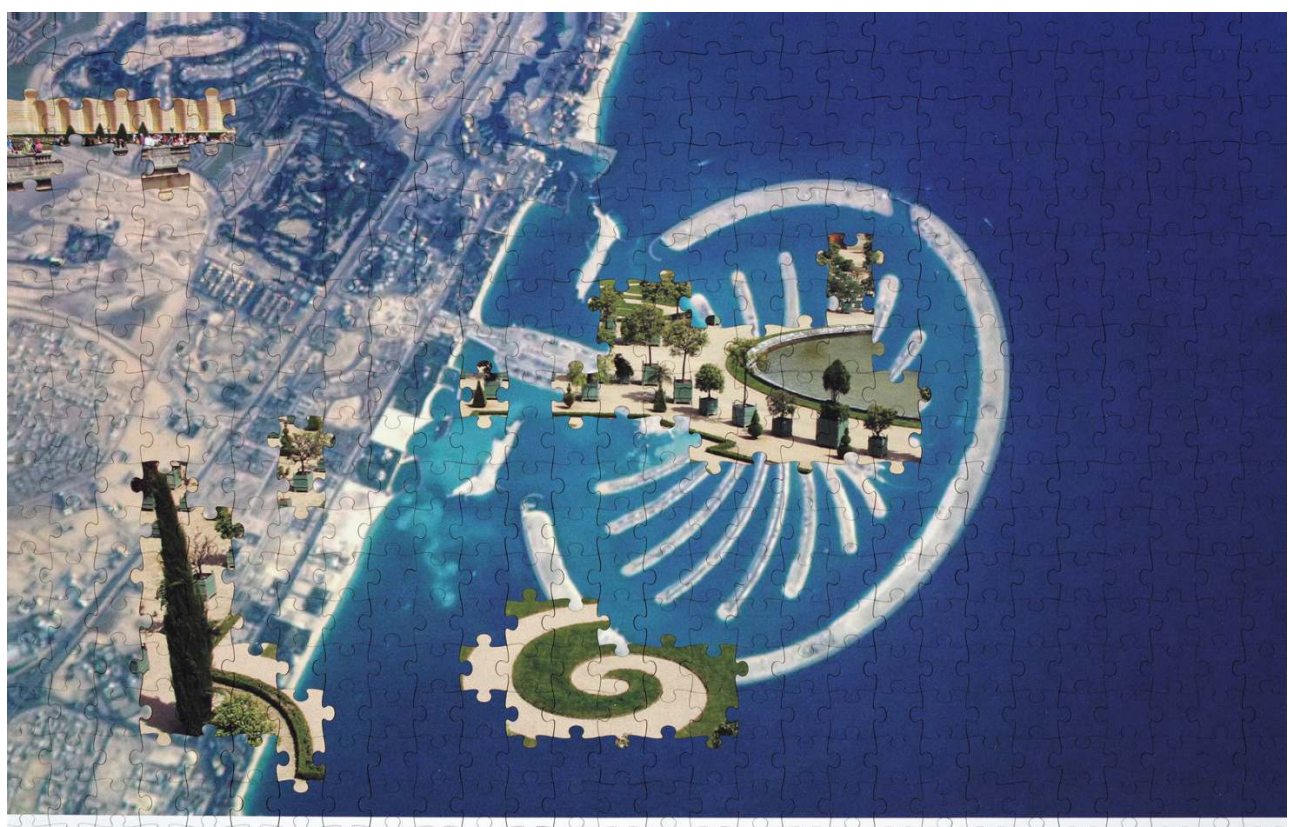

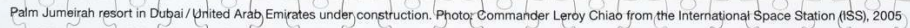


fig. 4.1.

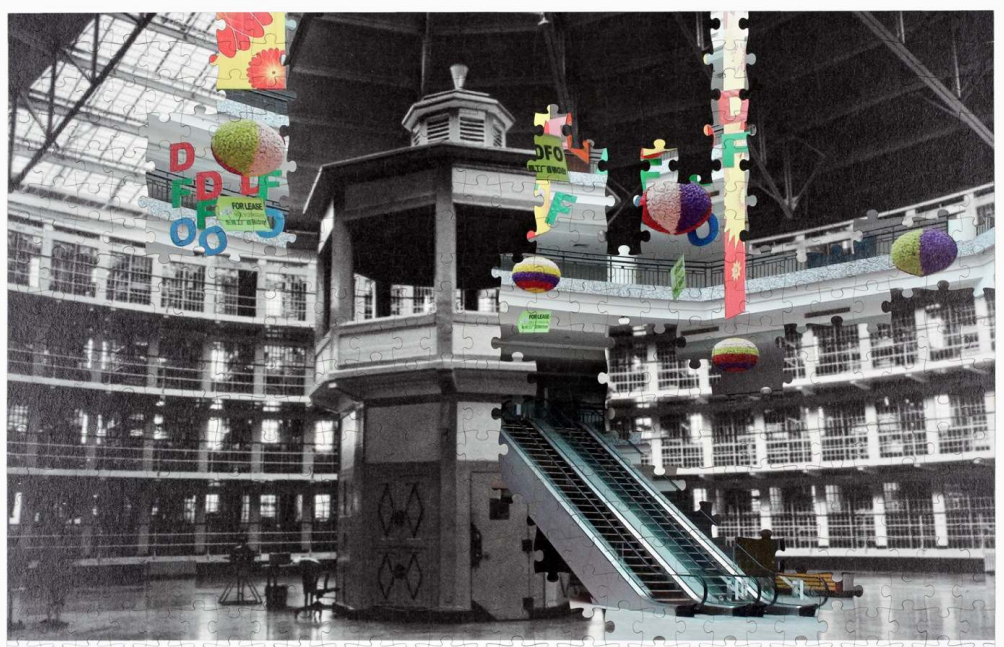

Fig. 4.2.

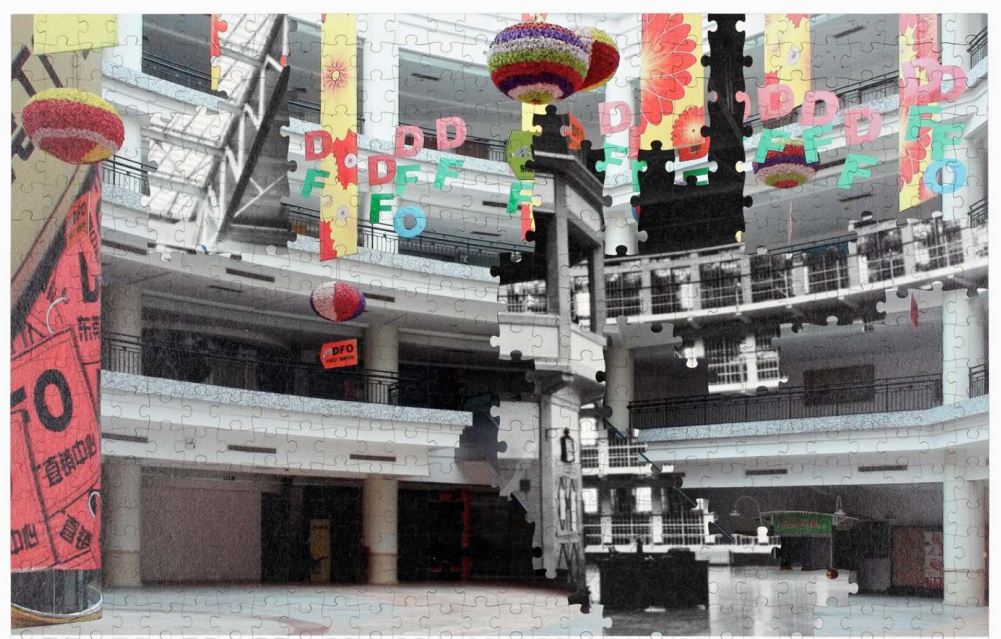

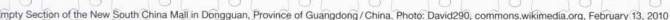

Pyramid, sphere, ornament, and atrium: The images of these four puzzle pairs show four iconic architectural forms in different historical periods and functional settings and reveal the ambiguous relation between form and function as well as between form and signification. Like a reversible figure, these images oscillate between ambivalent functions and significations, a sacred place is echoed in a shopping world, a symbol of 
revolutionary utopian architecture hosts surveillance devices, the ornament of a baroque garden is enlarged beyond human proportions transforming the physical texture of the earth and finally a shopping mall mirrors Bentham's ideal prison. The utopian, promising, or pleasurable features of one side of the reversible figure reveal an ugly face on the other side. Utopia turns dystopia. Is this due to the cynical character of technological progress, and thus a logical decline in an era dominated by technology?

produced in the framework of the research project Atlas of Arcadia. The arts-based research project was conducted by the authors of this essay and employs images of urban and technological developments to analyse social changes in our history since the fall of the Berlin Wall.

model for the Atlas of Arcadia is Walter Benjamin's collection of materials posthumously published as Arcades Project. The Arcades Project is based on text excerpts and also sporadic images related to the nineteenth century that Benjamin collected from 1927 until his death in 1940. This material is arranged to form what Benjamin called a "literary montage", a text assemblage that aims at highlighting social changes triggered by the industrial revolution in the nineteenth century without analytically interpreting the quotes. His credo was “I needn't say anything. Merely show.” (Benjamin 1999: 460)

Equally based on the principle of montage, our series Counterparts is inspired by an observation found in the convolute " $F$ : Iron Construction" of the Arcades Project. Benjamin noted that architectural forms frequently persist in spite of social and technological changes: When cast iron became an important building material in the nineteenth century it often appeared in the form of historical architectural styles. The innovative, if not "revolutionary building material" (Benjamin 1999: 157) did not automatically lead to equally innovative aesthetic forms, but imitated pre-existing styles and constructions instead. Iron parts were cast in the shape of Greek columns, train stations from the period resemble baroque palaces, etc.

With the following text excerpt Benjamin highlights this phenomenon:

I said earlier that in the period of 'sensibility,' temples were erected to friendship and tenderness; as taste subsequently turned to the classical style, a host of temples or temple-like buildings immediately sprang up in gardens, in parks, on hills. And these were dedicated not only to the Graces or to Apollo and the Muses; farm buildings, too, including barns and stables, were built in the style of temples (Jacob Falke, cited in Benjamin 1999: 151).

6 Twentieth century architecture was based on modern steel-frames developed in the late nineteenth century. It, however, eventually abandoned the historicist ornament in favour of the modernist ideal that form follows function. We will not discuss to what extent this is an attainable goal altogether. Instead, what we want to retain is that the modern steel frame buildings emancipated themselves from the style of temples. Does this mean, that Benjamin's observation is obsolete in a contemporary context?

7 No, we believe that his observation is still relevant: It concerns the ambiguous relation of form and content in history. Although this relation is fundamentally aleatory, it is disturbing to acknowledge this uncertainty because we would like to categorise the meaning of a form. To ponder the troubling relation between form and content in history let us look at the examples of the puzzle pairs separately.

8 The Pyramid Arena in Memphis, Tennessee, opened as a sports arena in 1991 and was eventually converted into a shopping complex. The architectural citation of the Egyptian pyramids is not just a historical cynicism that transforms a place of tombs serving as 
technologies of the afterlife into a temple of consumption and thereby adorns it with the glory of ancient history. ${ }^{1}$ Rather it is, and always has been a common practice to imitate historic architectural shapes. This practice hints at a human faculty that Benjamin considers a fundamental one: mimesis. The Romans copied architectural forms of the ancient Greeks; the Renaissance rediscovered ancient sources and thereby renewed art and the nineteenth century borrowed from whatever style needed for the symbolic value of a building, from neo-gothic churches to neo-classical parliaments. Looking at the juxtaposition of these two pyramids, however, makes us uneasy. What is it that causes this feeling of uneasiness? And what about the other puzzles? Do they give a similar impression?

9 Looking at Claude-Nicolas Ledoux's design for the gardener's house in Maupertuis from 1784, and at the radomes of the Waihopai Station in New Zealand, which are part of the "Echelon" spy network, we could suppose that it is only by coincidence that the utopian revolutionary architecture and the espionage facility share the same shape. Why does a spherical shape represent utopian architecture, and why do espionage facilities of all things need to be housed in spheres? We will not seek explanations to this here, but would prefer a clear formal differentiation of both buildings and the particular ideology associated with each one of them. Here again we are left with a feeling of unease.

The Palm Jumeirah resort in Dubai, here photographed while still under construction, could be interpreted as yet another example of the decorative arts, a magnified version of an ornament as we already find them in the baroque gardens of Versailles. But again we can perceive a disturbance in the harmony of the two images.

The mall-the epitome of a shopping paradise-usually includes a large atrium: just like the ideal prison architecture of the Panopticon! The sole difference is that the surveillance tower inside the prison space is replaced by panoramic stairways or transparent elevators. In this case the coherence is not accidental. The possibility to have an easy overview of the space from each standpoint within is as favourable for prison architecture as it is for the product range of a shopping mall. Thus our montage of both images puts the finger on the hidden flipside of the mall atrium and makes us uncomfortable even though the association with a Panopticon-like prison is dissimulated through the open escalators and the general glamorous style of the mall. Although in our example the blinding effect of the glitter is diminished by the fact that it shows an abandoned rather than busy mall.

In summary, we can note that the same architectural shapes can show up again randomly or be cited consciously. Set in contrast, they enter a discomforting dialogue. It is a quiet dialogue that is all too easy to miss, but that we want to listen to.

We said before that the relation between form and content is aleatory, but this doesn't prevent a form from being charged with history, with a hidden subtext that can flash up in a dialectical image. This is what we are aiming at when we confront two similar architectural shapes through images from different historical contexts: to instigate such a tacit dialogue in order to then closely listen to it.

The juxtaposition and interlacing of both images of each image pair tells us about the incredible technological progress achieved in the three millennia or centuries separating one from the other: We can build pyramids on an everyday basis like ordinary functional buildings, we created devices to eavesdrop on the entire world, and we are no longer content to trim our gardens into ornaments but extort entire ornamental islands from 
the sea. But while we accomplished all these technological achievements, the social achievements do not necessarily keep pace. The development of our societies lags behind technical development. Technical progress does not automatically entail social progress.

A donkey cart in downtown Memphis, a minivan and barbed wire fences in Ledoux's idealised landscape, an ornament scaled up to a point it can only be overlooked from aboard a plane: where does all this leave social progress? The dialectical image hot-wires the past to the present and vice versa. It brings them closer together than we would perhaps like. Through this short-circuit the past loses its mythical coating and the present its civilized edge.

But the story told by Counterparts is not one of moral decline. It is not, that the golden age of the past is distorted in our technological present. The example of the shopping mall recurs to its nasty flipside in a past image: aligning the shopping galleries of a mall with rows of prison cells reveals that the present is as entangled in mythologizing discourses as we might project on the past. Utopia is not imperatively linked to progress, nor does it hint to a lost paradise of the past. Rather there is no stable relation between form and content. As we hope to have demonstrated with the interlacing of the image pairs of Counterparts the confrontation of specific historical configurations makes apparent how we deal with form and content and how we shape our world. A worrying state of progress -deeply rooted in mythology-emerges in front of us. We believe this is what makes us uneasy.

This sobering finding, however, should not be the last point of this commentary. The mimetic quality of things produced by humans also contains a utopian potential. It includes the possibility of overstepping, a mimetic excess, that breaks through the limits of the given and negates it. We should regard the mimetic not as a mere means to an end but as an end in itself, as something that has the magical power to act as if it were real and thus suggests a different relationship between art and nature: art becomes part of nature and nature historically modifiable (Taussig 1993: 255). This means, it lies in our hands to use the mimetic potential and give it a utopian sense, and utopia the sense of mimetic excess within the given world.

\section{BIBLIOGRAPHY}

Benjamin, W. 1999. Arcades Project. (tr.) H. Eiland and K. McLaughlin. Cambridge: Harvard University Press.

Taussig, M. 1993. Mimesis and Alterity : A particular History of the Senses. New York / London: Routledge.

\section{NOTES}

1. Upon closer examination, the functions served by both buildings prove more similar than we would like to admit: the Egyptian pyramids are an expression of the religion around the god-like 
pharaohs; consumption, on the other hand, can be viewed as the religion of our time, shopping malls as 'cathedrals of consumption' (George Ritzer).

\section{AUTHORS}

\section{ANNA ARTAKER}

Anna Artaker is an artist and researcher at the institute for Art Theory and Cultural Studies at the Academy of Fine Arts Vienna. From the winter semester 2015 and onwards she will be Elise Richter-fellow at the same institution. Her work is exhibited internationally, most recently for example at the New Museum in New York, the Austrian Cultural Forum in London or the Museum of Modern Art in Vienna (MUMOK). In addition, Artaker is the winner of the EIKON Photography Competition, was awarded the Hilde Goldschmidt-Prize and was artist in residence in Mexico City and at the Cité internationale des arts in Paris.

\section{MEIKE SCHMIDT-GLEIM}

Meike Schmidt-Gleim is a philosopher and artist, and lives in Vienna and Paris. She has directed various research projects such as The History of Europe seen through the lens of the barbarian (20072010) and has exhibited as an artist in the Vienna Secession, the Salzburger Kunstverein or the Palais de Tokyo in Paris. Her publications include: The Meanings of Europe (editor), Routledge, London 2013; “Europe as imaginary object”, in: Parliament and Europe, Nomos Verlag, BadenBaden 2011; Die Regierung der Demokratie (monography), Passagen Verlag, Vienna 2009; as well as numerous publications on the ATLAS OF ARCADIA:

www.anthropologicalmaterialism.hypotheses.org 